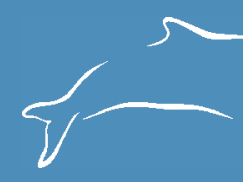

\title{
Distribution and conservation status of the Antillean manatee (Trichechus manatus manatus) in Honduras
}

\section{Article Info}

\begin{tabular}{|c|c|}
\hline Manuscript type & Article \\
\hline \multicolumn{2}{|l|}{ Article history } \\
\hline Received & 08 February 2011 \\
\hline Received in revised form & 25 September 2011 \\
\hline Accepted & 26 September 2011 \\
\hline Available online & 27 January 2014 \\
\hline \multicolumn{2}{|c|}{$\begin{array}{l}\text { Keywords: Antillean manatee, aerial surveys, Cuero y Salado } \\
\text { Wildlife Refuge, Honduras, La Mosquitia, Trichechus manatus } \\
\text { manatus, West Indian manatee }\end{array}$} \\
\hline \multicolumn{2}{|c|}{ Responsible Editor: Daniel M. Palacios } \\
\hline \multicolumn{2}{|c|}{ Citation: González-Socoloske, D., Taylor, C.R., and Rendon } \\
\hline \multicolumn{2}{|c|}{$\begin{array}{l}\text { Thompson, O.R. (2011) Distribution and conservation status of } \\
\text { the Antillean manatee (Trichechus manatus manatus) in Honduras. } \\
\text { Latin American Journal of Aquatic Mammals 9(2): 123-131. } \\
\text { http://dx.doi.org/10.5597/lajam00176 }\end{array}$} \\
\hline
\end{tabular}

\section{Daniel González-Socoloske ${ }^{\dagger, \neq, *}$, Cynthia R.} Taylor ${ }^{\S}$ and Olivia R. Rendon Thompson ${ }^{\mathrm{g}, t}$

${ }^{\dagger}$ Dept. of Earth and Biological Sciences, Loma Linda University, 11065 Campus Street, Loma Linda, CA 92350 USA

${ }^{\ddagger}$ Current Address: Department of Biology, Andrews University, Price Hall Rm 236, 4280 Administration Dr., Berrien Springs, Michigan 49104 USA ${ }^{\$}$ Aquatic Conservation Program, EcoHealth Alliance, 233 3rd St. North, Suite 300, St. Petersburg, FL, 33701 USA

'Dirección de Biodiversidad, Secretaria de Recursos Naturales y Ambiente, Tegucigalpa, Honduras

${ }^{\#}$ Current Address: School of Earth and Environment, University of Leeds, Leeds, LS2 9JT UK

*Corresponding author, e-mail: dg52@duke.edu

Abstract: The Antillean manatee, Trichechus manatus manatus, is among the most threatened mammals in Honduras, yet the last published study is from 1980. Since then, the North Coast of Honduras has experienced rapid population growth and land cover change possibly causing habitat loss for manatees. We conducted aerial, boat, and interview surveys between $2005-$ 2007 along the northern and remote eastern coasts of Honduras to assess the current status and distribution of manatees. In addition, we compiled all available data on manatee mortality from museum specimens, unpublished reports, and interviews to determine current threats. We averaged 1.2 manatee sightings per survey hour during six flights along the North Coast in March-April 2006 during 14.4 aerial survey hours. Sightings were mainly clustered in Cuero y Salado Wildlife Refuge (CSWR) and Rios Chapagua and Aguan, which we indentify as important conservation areas. Our total and average sightings per survey hour in CSWR were much lower than those reported in 1979-80, in spite of the area being protected since 1987. Our interviews indicate that manatees are still present on the eastern coast (La Mosquitia), however we observed none during 14.5 survey hours in June 2005 and April 2007. The major cause of known mortality from 1970-2007, based on 26 records, was due to entanglement in fishnets. Despite local and federal protection, manatees are still poached and opportunistically caught in fishnets. While some efforts have been made by local NGOs to raise public awareness for manatees, a national conservation program is highly recommended to centralize and coordinate efforts.

Resumen: El manatí antillano, Trichechus manatus manatus, es uno de los mamíferos más amenazados en Honduras, sin embargo, el último estudio publicado data de 1980. Desde entonces, la Costa Norte de Honduras ha experimentado un crecimiento rápido de población humana y cambios en el uso de suelo probablemente causando pérdida de hábitat para los manatíes. Realizamos muestreos aéreos y en lancha y también entrevistas entre 2005-2007 en la Costa Norte y en la remota costa del este de Honduras para evaluar el estado actual y la distribución de manatíes. Además, recopilamos todos los datos disponibles sobre mortalidad de manatíes mediante ejemplares en museos, reportes no publicados y entrevistas, para determinar las amenazas actuales. Realizamos seis muestreos aéreos de la Costa Norte entre marzo y abril del 2006, en los cuales registramos un promedio de 1.2 avistamientos por hora en un total de 14.4 horas de muestreos. Los avistamientos se ubicaron principalmente en el Refugio de Vida Silvestre Cuero y Salado (CSWR) y en los Ríos Chapagua y Aguan, que identificamos como importantes áreas de conservación. Los avistamientos totales y promedio por hora de muestreos en CSWR fueron mucho menores que los reportados en 1979-1980, a pesar de que esta área está protegida desde 1987. Nuestras entrevistas indican que los manatíes aún están presentes en la costa este (La Mosquitia), sin embargo, no se observó ningún manatí durante 14.5 horas de muestreos en junio 2005 y abril 2007. La mayor causa de mortalidad entre 1970 y 2007, basado en 26 reportes, se debió a que manatíes quedaban atrapados en redes de pesca. Si bien se han hecho algunos esfuerzos por parte de ONGs locales para incrementar el conocimiento del público en cuanto a los manatíes, se recomienda fuertemente que se desarrolle un programa de conservación nacional que centralice y coordine esfuerzos. 


\section{Introduction}

Manatees are herbivorous aquatic mammals that belong to the Order Sirenia. Due to the historical exploitation, current habitat loss and degradation, and their slow recruitment, all manatee species (Trichechus spp.) are categorized as Vulnerable on the IUCN Red List (IUCN, 2010). In addition, both subspecies of the West Indian manatee, Trichechus manatus, are further categorized as Endangered (Deutsch, 2008; SelfSullivan and Mignucci-Giannoni, 2008).

The Antillean subspecies, T. m. manatus, occurs in a fragmented distribution from southeastern Texas to northeastern Brazil, including the Greater Antilles (Lefebvre et al., 2001; Reynolds and Powell, 2002). In spite of their large geographic distribution, most studies of the Antillean manatee have concentrated in a few select areas including the Caribbean coast of Mexico and Belize, Puerto Rico, and Brazil (Mignucci-Giannoni and Beck, 1998; Lefebvre et al., 2000; Morales-Vela et al., 2000; Morales-Vela et al., 2003; Self-Sullivan et al., 2003; Olivera-Gómez and Mellink, 2005; Bacchus et al., 2009; Alves-Stanley et. al., 2010; Hunter et al., 2010). Much less is known about populations living in the rest of Central and South America.

In Honduras, historical manatee abundance and distribution are unknown (Klein, 1979; Lefebvre et al., 2001), however archaeological evidence suggests that manatee meat provided a substantial portion of the pre-historic diet of Mayans on the Bay Islands (Strong, 1935) and on the mainland of Honduras (Figure 1; McKillop, 1985). These early accounts suggest that manatees were abundant and had a wide distribution in Honduras, however sightings from aerial surveys in 1979-80 of the entire Caribbean coast of Honduras resulted in only two main locations: the rivers and coastal area between Rio Lean and Rio Salado, and Laguna Tansin (Figure 1; Rathbun et. al., 1983), of which the former was designated as a protected area for manatees in 1987. No subsequent studies have been conducted since that time, while the North Coast has experienced substantial human population growth and land cover change and is thus the area of Honduras that is the most vulnerable to manatee habitat loss (Pineda Portillo, 1997).

The objectives of our study were to conduct aerial, boat, and interview surveys to assess and update the current status and distribution of manatees in Honduras, identify ongoing threats, and evaluate the effectiveness of conserving manatees of the protected area on the North Coast by providing a roughly 25 -year contrast since the last available data.

\section{Study area}

Our study area consisted of the major rivers, lakes and immediate coastal area of the Caribbean coast of Honduras (Figure 1), which is $c a$. $700 \mathrm{~km}$ long. The Caribbean coast can be divided into two major sections that differ greatly in geology, topography and human impact. In this study we refer to the area between Rio Motagua (on the border with

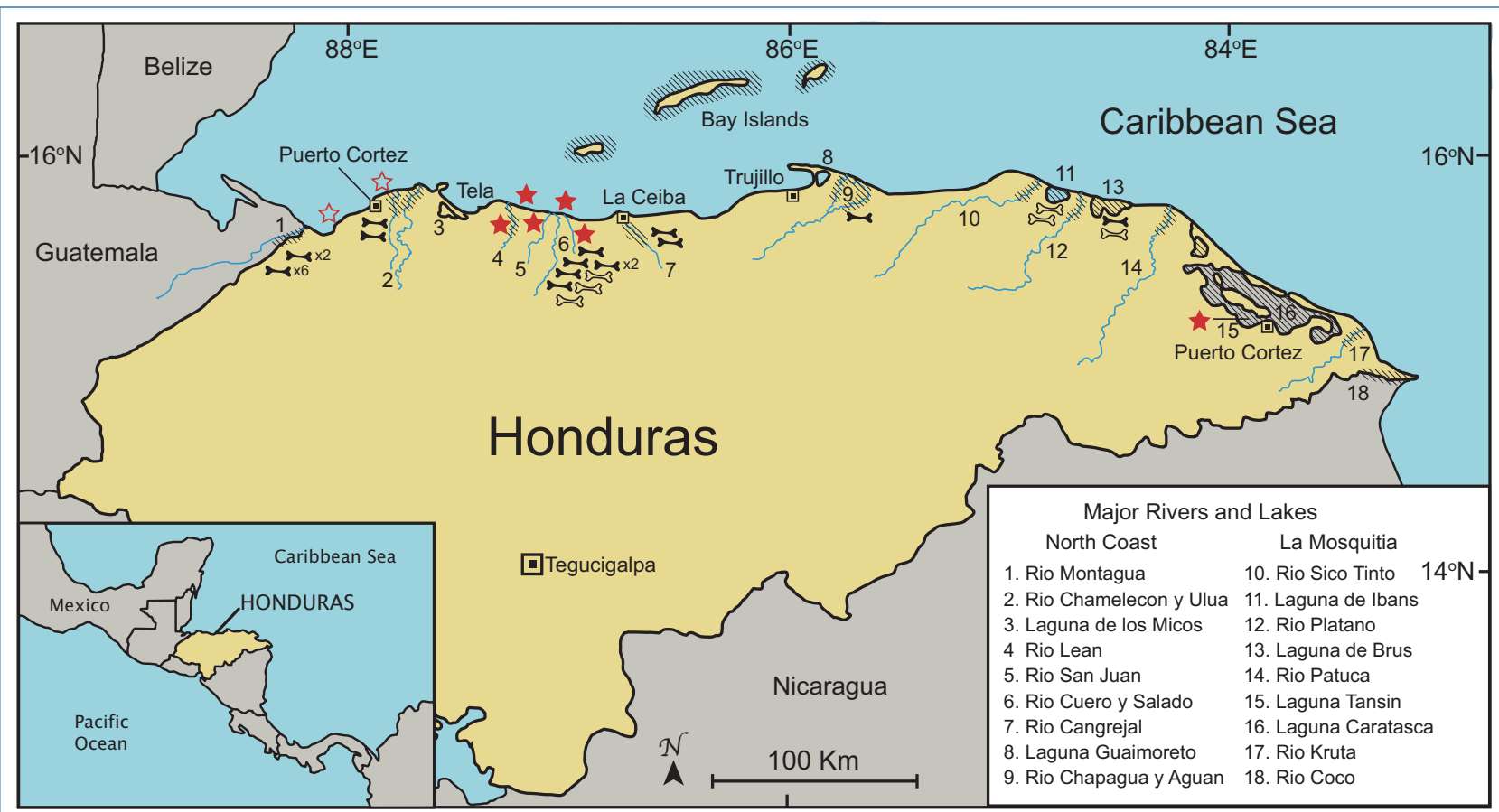

Figure 1. Map of study area with historical distribution (shaded area), mortality records, and previous aerial survey sightings of Antillean manatees in Honduras. Historic range was determined by previous aerial survey sightings from 1979-80 (solid stars), 2000 and 2005 (open stars), unpublished reports and historic interview data. Offshore and inland sightings appear in the ocean and next to the corresponding river or lake, respectively. Manatee mortalities correspond to Table 1 and are divided into records from 1970-1999 (solid bone symbol) and from 20002007 (open bone symbol). 


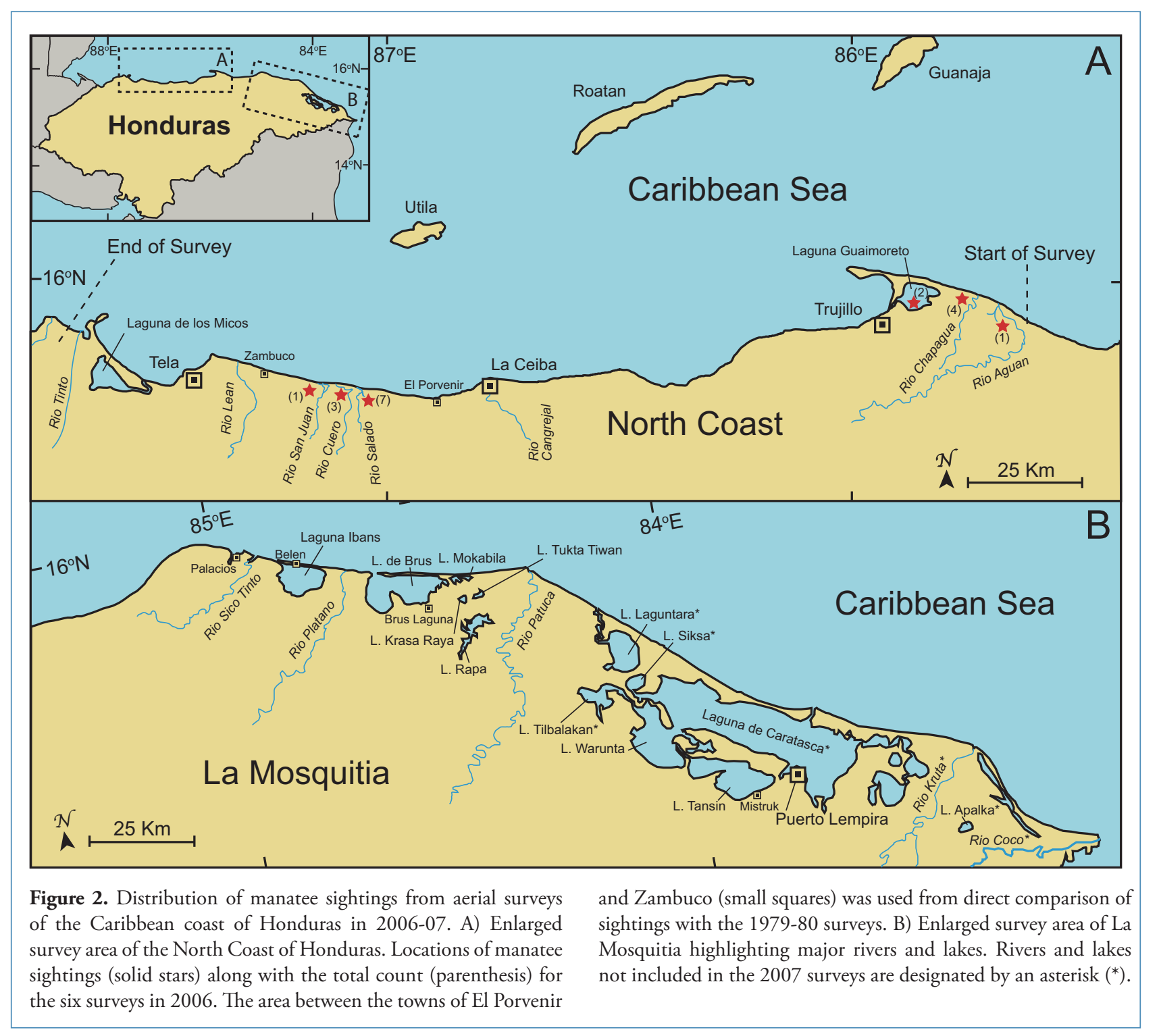

Guatemala) and Rio Aguan (east of Trujillo) as the North Coast, and the area between Rio Aguan and Rio Coco (on the border with Nicaragua) as La Mosquitia (Figure 1). Five major river basins on the North Coast empty into the Caribbean: 1) Rio Motagua, 2) Rios Ulua and Chalamecon, 3) Rios San Juan, Cuero and Salado which make up the protected area Cuero y Salado Wildlife Refuge (CSWR), 4) Rio Cangrejal, and 5) Rios Aguan and Chapagua. The area between these rivers contains two mountain ranges that reach the shore with peaks as high as $4000 \mathrm{~m}$. This area of Honduras has four major cities and has a relatively high human population density. In contrast, the expansive lake and wetland system of the eastern coast, known as La Mosquitia, contains no mountain ranges, only one large city and a very low human population density. The major rivers in La Mosquitia are: 1) Rio Sico Tinto, 2) Rio Platano, 3) Rio Patuca, 4) Rio Kruta, and 6) Rio Coco. The major lakes in La Mosquitia are: 1) Laguna Brus, 2) Laguna Ibans, and 3) Laguna Caratasca, the latter comprising at least 20 smaller lakes (Figure 1).

\section{Methods}

Interviews We interviewed a total of 53 local community members in seven locations (San Pedro Sula, Tela, Rio Salado, La Ceiba, Utila, Roatan, and Trujillo; Figure 2A) on the North Coast and five locations (Palacios, Belen, Brus Laguna, Mistruk, and Puerto Lempira; Figure 2B) in La Mosquitia between 2005-2007 for information on manatees and mortality cases.

Secondary data We gathered information on manatee mortality and historical distribution from previous published studies, unpublished reports, and museum specimens from the Archaeological Museum of San Pedro Sula and the Museum of Natural History of the National Autonomous University of Honduras (UNAH) in Tegucigalpa.

Field Surveys We conducted 6 aerial surveys along the North Coast between Rio Aguan and Rio Tinto in 2006 (Figure 2A). The first three did not include Rio Aguan, as we mistakenly identified Rio Chapagua as Rio Aguan during these surveys. Rio Tinto was selected as the western limit 
because a contemporary study of manatee distribution in the Gulf of Honduras (southern Belize to western Honduras) included the area from the border of Guatemala to Rio Tinto ${ }^{1}$.

We conducted three aerial surveys in La Mosquitia in 2007 including most of the major lakes and rivers (Figure 2B). Due to budget and time constraints we selected lakes and rivers with the highest chance of seeing manatees based on previous interviews and unpublished reports. Because of the immense size and lack of submerged and floating vegetation due to marine water influence we did not include Laguna Caratasca. In addition, despite extensive aerial surveys of this lake in 1995, no manatee sightings were recorded (G. Cruz unpublished data). We also did not survey the lakes and rivers east of Puerto Lempira due to security concerns with the border of Nicaragua.

We conducted all aerial surveys during the dry season, March and early April, because water conditions were clearer and most favourable for viewing manatees, and a more valid comparison could be made with previous surveys (Rathbun et al., 1983). Flights were conducted in a Cessna 206 at an altitude of $200-250 \mathrm{~m}$ and an airspeed of $130-150 \mathrm{~km} / \mathrm{hr}$ (cf Ackerman 1995, Lefebvre et al., 1995), between 0800$1400 \mathrm{~h}$ along the North Coast and between 0900-1400h in La Mosquitia. Surveys on the North Coast were flown parallel to the coast from east to west, $500 \mathrm{~m}$ from the shore, because manatees preferentially use near shore coastal areas, estuaries, rivers and lakes (Reynolds and Odell, 1991; Olivera-Gómez and Mellink, 2002). River mouths, lakes and lagoons were covered more intensely than the coastal area and we also intensively circled sites where manatees were sighted to determine numbers (variable effort recount; Lefebvre and Kochman, 1991). Flight paths were recorded with an onboard GPS. Wind direction, wind speed, sea state (Beaufort scale), and cloud cover were recorded on data sheets at the start of each survey, as all of these can influence visibility during surveys. Although aerial surveys provide the best means of obtaining manatee distribution and relative abundance over large areas (Ackerman, 1995; Lefebvre et al., 1995), there are several inherent biases (Marsh and Sinclair, 1989; Lefebvre et al., 1995), including visibility bias and perception bias. Independent observers can reduce perception bias, but because the rate of manatee encounters was low, the observers in our surveys were not independent and were in constant communication during the flights. We repeated the survey path on the North Coast six times in an effort to reduce the effect of visibility bias (both perception and availability bias) and absence bias.

Three observers were located on the right side of the aircraft with the door removed for better visibility during all surveys;

${ }^{1}$ Quintana-Rizzo, E. 2005. Estudio sinóptico de la distribución y abundancia relativa del manatí (Trichechus manatus) en el Golfo de Honduras en el periodo de Mayo-Junio 2005. Reporte Técnico para el Comitato Internazionale per lo Sviluppo del Popoli (CISP), Ciudad de Guatemala, Guatemala. 33 pp. the observer in front helped navigate and recorded data while the other two only observed. During the surveys the plane flew at a 45-degree angle favouring the side of the observers so that a greater area of observation could be seen. In the coastal marine areas (offshore), observers could see from the shore out to $500 \mathrm{~m}$. In the rivers and lakes (inland) the plane flew to one side of the body of water at a 45-degree angle so that the observers could see the entire body of water from the waters edge. In the case of large lakes, the shore was outlined followed by various transverse passes as was necessary to cover the area (see Morales-Vela et al., 2003). Water visibility was variable, but coastal marine waters were generally more transparent than the turbid and tannin-stained rivers and lakes. The same set of three observers participated in all six surveys along the North Coast and a different set of observers participated in all three surveys of La Mosquitia. Manatee sightings, boats, and the presence of gillnets were recorded on data sheets and maps. Boat surveys were conducted in July 2005 of Laguna de Brus, Laguna de Ibans, and Rio Platano in La Mosquitia between 0800-1200h. Two experienced observers were used during boat surveys. Boat surveys were conducted in a dugout canoe equipped with a $25 \mathrm{hp}$ outboard motor at a slow velocity $(2-5 \mathrm{~km} / \mathrm{h})$.

\section{Results}

Compiled secondary data and our interviews documented the presence of manatees in most major rivers, lakes and lagoons along the coast of Honduras, with the exception of Laguna de los Micos and Laguna Guaimoreto (Figure 1). We compiled 26 mortality records (Table 1$)$; most $(\mathrm{n}=19)$ were from the North Coast during 1970-99 (Figure 1). Deaths since 1999 were clustered in Rio Cuero and Rio Salado ( $\mathrm{n}=$ 3) on the North Coast, and in Lagunas de Brus and Laguna de Ibans $(\mathrm{n}=3)$ in La Mosquitia (Figure 1). Most deaths ( $\mathrm{n}$ =13) were due to entanglement and subsequent drowning in fishnets.

North Coast Six aerial surveys covering the same flight path were conducted on 29-31 March and 2-4 April, 2006 (Table 2). Cloud cover during the surveys varied from $0 \%$ to $100 \%$ and averaged $50 \%$. Sea state on the Beaufort scale was 1, except for 29 March, when it was 3. Flying conditions were favorable and followed the pattern of calm or no wind during the morning and light winds up to $15 \mathrm{~km} / \mathrm{h}$ in the early afternoon.

We totalled $14 \mathrm{~h} 23 \mathrm{~min}$ of aerial survey time during the six surveys between Rio Aguan to Rio Tinto in which we recorded a total of 18 manatee sightings (Table 2 ). The average $( \pm S D)$ survey duration was $143 \pm 0.13 \mathrm{~min}$ and we averaged $1.2 \pm 0.2$ manatee sightings per survey hour (Table 2). Manatee sightings clustered around 1) Rio Salado, Rio Cuero, and Rio San Juan (11 of 18), and 2) Rio Chapagua, and Rio Aguan (5 of 18). Two animals were sighted in Laguna Guaimoreto (Figure 2A). No manatees were seen west of Rio San Juan. 
Table 1. Summary of 26 records of Antillean manatee in Honduras ${ }^{\mathrm{a}}$.

\begin{tabular}{|l|c|c|c|c|c|c|c|}
\hline Date & $\begin{array}{c}\text { Specific } \\
\text { Location }\end{array}$ & $\begin{array}{c}\text { No. } \\
\text { of Manatees }\end{array}$ & $\begin{array}{c}\text { Cause } \\
\text { of death }\end{array}$ & Age & Sex & $\begin{array}{c}\text { Association } \\
\text { with other } \\
\text { manatees }\end{array}$ & Source $^{\text {c }}$ \\
\hline $1970-80$ ? & 2. Rio Ulua & 1 & U death & A & U & Alone & MS \\
\hline 1974 & 13. Laguna de Brus & 1 & Drowning & C & U & Alone & MS \\
\hline 1976 & 7. Rio Cangrejal & 1 & Hunted & A & U & Alone & PS \\
1977 & 7. Rio Cangrejal & 1 & Hunted & A & U & Alone & PS \\
\hline 1978 & 6. Rio Salado & 2 & U deaths & A (2) & U (2) & Group of 4 & PS \\
\hline 1979 & 6. Rio Salado & 1 & U death & A & U & Pair & PS \\
\hline 1980 & 6. Cuero y Salado & 1 & Drowning & A & U & Alone & MS \\
\hline 1983 & 1. Rio Motagua & 6 & Drowning & A (5), C & U (6) & Group of 6 & CS \\
\hline 1984 & 2. Rio Monje & 1 & Drowning & A & U & Group of 11 & MS \\
\hline 1989 & 1. Laguna Jaloa & 2 & Hunted & A, C & F, U & Pregnant & CS \\
1990 & 6. Cuero y Salado & 1 & Drowning & A & U & Alone & CS \\
\hline 1992 & 6. Cuero y Salado & 1 & U death & C & U & Alone & CS \\
\hline 1996 & 9. Rio Aguan & 1 & Drowning & A & U & Alone & CS \\
\hline 2000 & 6. Rio Salado & 1 & Drowning & A & U & Alone & MS, CS \\
\hline 2000 & 13. Laguna de Brus & 1 & Drowning & A & U & Alone & MS \\
\hline 2004 & 11. Laguna de Ibans & 1 & Hunted & A & F & Alone & MS, CS \\
\hline 2005 & 6. Rio Salado & 1 & U death & C & M & Alone & MS, CS \\
\hline 2005 & 11. Laguna de Ibans & 1 & U death & A & M & Alone & CS \\
\hline 2007 & 6. Rio Salado & 1 & U death & C & M & Alone & CS \\
\hline
\end{tabular}

${ }^{a}$ Drowning, death by gillnet or other form of entanglement, accidental or intentional; Hunted, killed with harpoon, axe or gun; U, Unknown; A, Adult $(>200 \mathrm{~cm})$; C, Calf $(<200 \mathrm{~cm})$; M, male; F, Female

${ }^{\mathrm{b}}$ Number corresponds to classification in Figure 1 of the nearest major river.

c MS, Museum specimen, either in The Archeological Museum, San Pedro Sula; or The Museum of Natural History of the National Autonomous University of Honduras, Tegucigalpa; PS, Previous study, Rathbun et al., 1983 or Klein, 1979; CS, Current study, from our interviews and unpublished reports.

We recorded a total of 11 manatee sightings (all adults) between the towns of El Porvenir and Zambuco (Figure 2A) during the six surveys, and all were within rivers and costal lakes. We surveyed this area a total of $3 \mathrm{~h} 17 \mathrm{~min}$, averaging $32.8 \pm 5.7$ min per survey, which was very similar to the six surveys in 197980 of the same area (Table 3$)$. We averaged $3.3 \pm 0.4( \pm$ SE) manatee sightings per survey hour for this region, which was much lower than the average $(13.3 \pm 2.4)$ sighted in 1979-80 (Table 3).

La Mosquitia We totalled $3 \mathrm{~h} 37 \mathrm{~min}$ of aerial survey time during three surveys averaging $72 \pm 42.8$ min per survey on $1-2$ and 4 April 2007. Despite excellent survey conditions and very good water visibility we did not sight any manatees during these surveys. In addition, we totalled $11 \mathrm{~h}$ of boat survey time on 1617 and 19 July 2005 of Laguna Ibans, Laguna de Brus, and Rio Platano. No manatees were observed during boat surveys.

\section{Discussion}

The overall distribution of manatee sightings on the North Coast of Honduras did not greatly differ from the distribution documented in 1979-80. Most (11 of 18) of our sightings occurred within the protected area CSWR, where other recent sightings have been reported by boat surveys using sonar (Gonzalez-Socoloske et al., 2009). In addition, a substantial number of sightings were clustered in both Rio Aguan and Rio Chapagua (5 of 18), which represent the second-most important area for the remaining manatees of the North Coast of Honduras. The distribution of our sightings along the North Coast varied greatly between surveys, even though the total number of manatee sightings per survey remained relatively constant (Table 2), supporting the conclusion that repeated surveys are necessary to determine distribution (Olivera-Gómez and Mellink, 2002). The effect of visibility bias may be magnified when surveying 
Table 2. Summary of results from aerial surveys of major rivers and lagoons on the North Coast of Honduras in 2006.

\begin{tabular}{|c|c|c|c|c|c|c|c|c|c|c|c|c|c|c|}
\hline 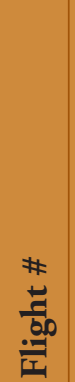 & 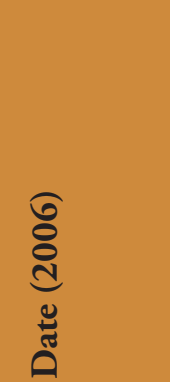 & 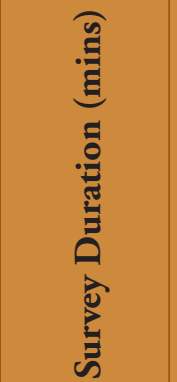 & 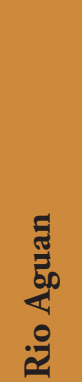 & 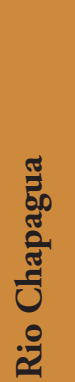 & 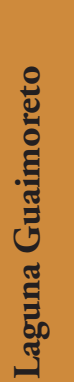 & 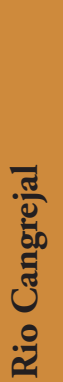 & 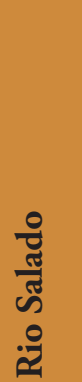 & 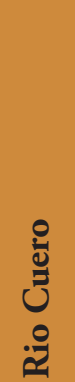 & 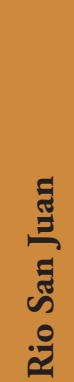 & 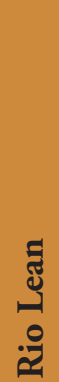 & 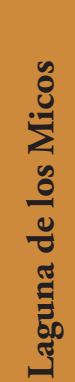 & 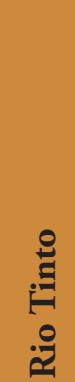 & 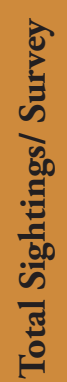 & 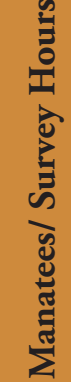 \\
\hline 1 & March 29 & 160 & $\mathrm{NS}^{\mathrm{a}}$ & 0 & 0 & 0 & 1 & 2 & 0 & 0 & 0 & NS & 3 & 1.1 \\
\hline 2 & March 30 & 160 & NS & 1 & 2 & 0 & 0 & 0 & 1 & 0 & 0 & 0 & 4 & 1.5 \\
\hline 3 & March 31 & 143 & NS & 1 & 0 & 0 & 2 & 0 & 0 & 0 & 0 & 0 & 3 & 1.3 \\
\hline 4 & April 2 & 135 & 1 & 0 & 0 & 0 & 2 & 0 & 0 & 0 & NS & 0 & 3 & 1.3 \\
\hline 5 & April 3 & 135 & 0 & 2 & 0 & 0 & 0 & 1 & 0 & 0 & NS & 0 & 3 & 1.3 \\
\hline \multirow[t]{3}{*}{6} & April 4 & 130 & 0 & 0 & 0 & 0 & 2 & 0 & 0 & 0 & NS & 0 & 2 & 0.9 \\
\hline & Total & $14 \mathrm{~h} 23 \mathrm{~m}$ & 1 & 4 & 2 & 0 & 7 & 3 & 1 & 0 & 0 & 0 & 18 & \\
\hline & Mean & 143.8 & 0.3 & 0.7 & 0.3 & 0 & 1.2 & 0.5 & 0.2 & 0 & 0 & 0 & 3.0 & 1.2 \\
\hline
\end{tabular}

${ }^{a} \mathrm{NS}=$ Area not surveyed.

locations of low manatee densities, as the likelihood of seeing an animal is greater when they are in a group. This may explain why Rathbun et al. (1983) had no manatee sightings in Rio Aguan and Rio Chapagua during their single survey of the area in 1979.

We observed two manatees during one of the surveys of Laguna Guaimoreto. This represents the first report of manatees in this lake. The pair may have been travelling, because they were only sighted on one of the six surveys.

Even with the most liberal estimates, the population of manatees on the North Coast is very low. Our surveys averaged 1.2 manatees per survey hour for the northern coast and 3.3 manatees per survey hour between El Porvenir and Zambuco, while a contemporary study of the Gulf of Honduras (Monkey River, Belize to Tela, Honduras) found 13.3 manatees per survey hour for all of Guatemala and 80.2 manatees per survey hour for southern Belize during a single survey ${ }^{1}$. Surveys covering all of Belize and Chetumal Bay, in southern Mexico averaged between 14.3-23.3 manatees per survey hour (Morales-Vela et al., 2003). Nicaragua also appears to have a larger manatee population where 40 were estimated to be killed annually (Jiménez, 2002) and an average of 3.9 manatees per survey hour were sighted during aerial surveys in $1994^{2}$.

Our aerial surveys of the protected area CSWR (approximately the area between the coastal towns of El Provenir and Zambuco) were comparable to the surveys in 1979-80 (see Table 3). Our survey altitude was slightly higher than in the previous study

${ }^{2}$ Carr, T. (1994) The manatees and dolphins of the Miskito Coast Protected Area, Nicaragua. Document No. PB 94-170354. National Technical Information Service. Springfield, Virginia, USA. 19 pp. due to new safety regulations. While this might slightly bias against us, our number of observers (always three) and slightly longer average survey duration $(32.8 \pm 5.7 \mathrm{~min}$ versus $30.1 \mathrm{~min})$ provided an increased probability of sighting manatees.

All of our manatee sightings between El Porvenir and Zambuco were of adults and were located inland within the rivers and lakes, whereas calves (17\%) and animals offshore in coastal marine waters (30\%) were relatively common during the 1979-80 surveys (Table 3). This does not mean calves are not present, as single calves were found dead in early January 2005 and August of 2007 in Rio Salado (Table 1), but rather that they are more difficult to see especially in conditions of very low water visibility. The absence of sightings in marine areas during the 2006 surveys is puzzling, but may simply reflect low densities of animals and thus a lesser likelihood of spotting an animal travelling coastally from river to river.

Rio Cuero, Rio Salado and Rio San Juan were designated as a protected area (CSWR) in 1987 specifically to protect manatees. Manatees in Florida have been reported to preferentially use protected areas, thus resulting in total counts slowly increasing from year to year (Provancha and Provancha, 1988). Based on this observation, we expected to locate more manatees within CSWR during our surveys compared to those conducted in 1979-80, when the area was not protected. However, in spite of protection, primarily of the habitat, manatee sightings have decreased - probably because manatee deaths have been continually reported from this region (Figure 1; Table 1).

The North Coast of Honduras had the most mortality records (Table 1), which may result from a bias due to the higher likelihood of manatee deaths being reported in this 
Table 3. Comparison of aerial surveys between El Porvenir and Zambuco on the North Coast of Honduras in 1979-80 and 2006.

\begin{tabular}{|l|c|c|}
\hline \multicolumn{2}{|c|}{ Year } \\
\hline Number of flights & $1979-80^{\mathrm{a}}$ & 6 \\
\hline Survey area & 6 & El Porvenir to Zambuco \\
\hline Ave. survey duration & El Porvenir to Zambuco & $32.8 \pm 5.7 \mathrm{~min}$ \\
\hline Speed & $30.1 \mathrm{~min}$ & $130-150 \mathrm{~km} / \mathrm{hr}$ \\
\hline Altitude & $120-160 \mathrm{~km} / \mathrm{hr}$ & $200-250 \mathrm{~m}$ \\
\hline Number of observers & $150-300 \mathrm{~m}$ & 3 \\
\hline Time of year & $2-3$ & March and April \\
\hline Total manatee count & March and May & 11 \\
\hline Ave. sightings per & 40 & $3.3 \pm 0.4$ \\
survey hour \pm SE & $13.3 \pm 2.4$ & $0(0)$ \\
Offshore sightings & & $0(0)$ \\
\hline (\% of total) & $12(30)$ & \\
\hline Calves (\% of total) & 4 (17) & \\
\hline
\end{tabular}

a Data from unpublished trip report, Rathbun, G. and Powell, J. (1979) National Fish and Wildlife Laboratory, Sirenia Project, 13 p. and Rathbun et al., 1983.

${ }^{\mathrm{b}}$ Out of a total of 23 sightings in 1979, calves were not counted during surveys in 1980.

region. In addition, the extent of the geographic distribution of reported manatee mortality records on the North Coast seems to have decreased. Although the majority of the manatee mortality records concur with the survey sightings in Rio Cuero, Rio Salado and Rio San Juan, there have been no recent manatee sightings in Rio Cangrejal or Rio Lean (Rathbun et al. 1983; Figure 1).

Even though we did not conduct aerial surveys of the region between Rio Motagua (on the border with Guatemala) and Rio Tinto (west of Tela), manatees occur there based on our interviews, mortality records (Table 1), and aerial survey sightings by other studies in $2000^{3}$ and $2005^{1}$. However, those eight sightings were all in the coastal marine habitat, suggesting that the manatees were likely travelling between rivers and lakes.

Manatees formerly occurred in the Bay Islands (Strong, 1935), but they have not been reported there since the 1970s (Davidson, 1974; Rathbun et al., 1983), which is consistent with our findings from interviews.

Most of La Mosquitia is designated as a protected area, but our interviews indicate that manatees are still opportunistically

\footnotetext{
${ }^{3}$ Auil, N.E. (2000) Aerial surveys for the Gulf of Honduras: Monkey River, Belize to Tela, Honduras, March 29-31. Coastal Zone Management Authority and Institute, Belize City, Belize. 5 pp.
}

hunted for local consumption; proper enforcement is difficult due to the large area. Due to its low human population density and extensive untouched habitat, this area is expected to have the greatest number of manatees within Honduras. Despite this, we observed no manatees during our $14.5 \mathrm{~h}$ of boat and aerial surveys, in contrast to 71 manatees sighted during $18 \mathrm{~h}$ of aerial surveys along the neighbouring Miskito Coast of Nicaragua ${ }^{2}$.

To our knowledge, no manatee mortality has resulted from boat collisions and no manatees have been reported with propeller scars in Honduras. The most recorded deaths (50\% mortality cases; Table 1) resulted from entanglements and drowning in fishnets. Fishermen interviewed on the North Coast and in La Mosquitia indicate that manatees are still occasionally killed by fishnets, such as a single adult in both Rio Salado and Laguna de Brus in 2000 (Table 1). The use of fishnets is still widespread in Honduras and may be the biggest threat on the North Coast, while in La Mosquitia manatees are still actively hunted opportunistically. In the protected area CSWR the use of fishnets is prohibited and punishable by a hefty fine and confiscation of the nets, which has greatly reduced their use. However several young manatees have been found dead in the past few years such as a young, $150 \mathrm{~cm}$-long calf found dead in Rio Salado in 2005; local people indicated that it died by entanglement 
in fishing gear. However, no external marks were found on the animal and there were no fishnets found nearby when it was discovered. We recovered the bones of this animal in 2007 and prepared the skeleton for display in the visitor center of CSWR. Based on the extreme dental wear of this animal, we speculate that it was orphaned and starved to death. In Florida, young manatees prematurely separated from their mothers reportedly wear down their teeth by consuming large quantities of sand and dirt (G. Bossart, per. comm, September 2006).

Based on our results we recommend that due to the high mortality of manatees by fishnets, existing laws prohibiting the use of fishnets in protected areas (such as CSWR) continue to be strongly enforced. In addition, the practice of extending fishnets across the whole river mouth should be prohibited along the entire coast. However, because of the delicate nature of such laws and the difficulty of enforcing them over large geographic areas, we suggest that a local conservation effort should accompany the fishnet restrictions by providing education about the harmful effects they have on manatees. In addition, we recommend that CSWR and Rios Aguan and Chapagua be surveyed regularly either by boat or aerially to monitor for changes in relative abundance and distribution of manatees and to monitor human impact. Finally, we propose the consideration of the development of a national conservation program for manatees in Honduras with participates from local NGOs, government agencies, and academics so that conservation efforts can be centralized and coordinated and mortality cases can continue to be compiled to evaluate continued threats in Honduras.

\section{Acknowledgements}

We would like to thank M. Gangaware and C. Schroll of LightHawk and J. Herrero of USAID-Honduras for assistance in providing the aerial surveys. We are grateful to S. Flores and G.A. Cruz from the National Autonomous University of Honduras (UNAH) for their assistance in data collection during aerial surveys on the North Coast and for access to museum specimens at the Museum of Natural History, Tegucigalpa, respectively. We would like to especially thank G. Rathbun and J. Powell for their unpublished data, which was made available to us by the U.S. Geological Survey, Sirenia Project. This project was funded by a grant from USAID-MIRA Honduras to D.G.S. and R.E. Ford. This study was conducted under a Honduran federal permit and approved by Loma Linda University's Institutional Animal Care and Use Committee. We thank K. Acevedo-Whitehouse and two anonymous reviewers for helpful comments on this manuscript.

\section{References}

Ackerman, B. B. (1995) Aerial surveys of manatees: a summary and progress report. Pages 13-33 in O'Shea, T. J., Ackerman, B. B. and Percival, H.F. (Eds) Population Biology of the Florida Manatee. National Biological Service Information and Technology Report 1, Washington, DC, USA.

Alves-Stanley, C. D., Worthy G. A. J. and Bonde R. K. (2010) Feeding preferences of the West Indian manatee in Florida, Belize, and Puerto Rico as indicated by stable isotope analysis. Marine Ecology Progress Series 402: 255-267. http://dx.doi.org/10.3354/meps08450

Bacchus, M. -L. C., Dunbar, S. G. and Self-Sullivan, C. (2009) Characterization of resting holes and their use by the Antillean manatee (Trichechus manatus manatus) in the Drowned Cayes, Belize. Aquatic Mammals 35 (1): 62-71. http://dx.doi.org/10.1578/AM.35.1.2009.62

Davidson, W. V. (1974) Historical geography of the Bay Islands, Honduras: Anglo hispanic conflict in the Western Caribbean. Southern University Press. Birmingham, Alabama, USA.

Deutsch, C. J. (2008) Trichechus manatus latirostris in IUCN 2010. IUCN Red List of Threatened Species. Version 2010.4. Available online at [<www.iucnredlist.org $>$ Consulted on 8 February 2011]

Gonzalez-Socoloske, D., Olivera-Gomez, L. D. and Ford, R. E. (2009) Dectection of free-ranging West Indian manatees Trichechus manatus using side-scan sonar. Endangered Species Research 8: 249-257. http://dx.doi.org/10.3354/esr00232

Hunter M. E., Auil-Gomez N. A., Tucker K. P., Bonde R. K., Powell J. and McGuire P. M. (2010)_Low genetic variation in the regionally important Belize manatee and evidence of low intra-populational and sub-species dispersal. Animal Conservation 13, 592-602.

http://dx.doi.org/10.1111/j.1469-1795.2010.00383.x

IUCN (2010) IUCN Red List of Threatened Species. Version 2010.4. [Available online at <www.iucnredlist.org>. Consulted on 8 February 2011].

Jimenez, I. (2002) Heavy poaching in prime habitat: the conservation status of the West Indian manatee in Nicaragua. $\operatorname{Oryx} 36$ (3): 272-278.

http://dx.doi.org/10.1017/S0030605302000492

Klein, E. H. (1979) Review of the status of manatee (Trichechus manatus) in Honduras, Central America. Ceiba 23 (1): 21-28.

Lefebvre, L. W., Ackerman, B. B., Portier, K. M. and Pollock, K. H. (1995) Aerial survey as a technique for estimating trends in manatee population size - problems and prospects. Pages 63-74 in O'Shea, T.J., Ackerman, B.B. and Percival, H.F. (Eds) Population biology of the Florida manatee. National Biological Service Information and Technology Report 1, Washington, DC, USA. 
Lefebvre, L. W. and Kochman, H. I. (1991) An evaluation of aerial survey replicate count methodology to determine trends in manatee abundance. Wildlife Society Bulletin 19 (3): 298-309.

Lefebvre, L. W., Marmontel, M., Reid, J. P., Rathbun, G. B. and Domning, D. P. (2001) Status and biogeography of the West Indian manatee. Pages 425-474 in Wood, C. A. and Sergile, F. E. (Eds) Biogeography of the West Indies: Patterns and perspectives. CRC Press. Boca Raton, FL, USA.

Lefebvre, L. W., Reid, J. P., Kenworthy, W. J. and Powell, J. A. (2000) Characterizing manatee habitat use and seagrass grazing in Florida and Puerto Rico: implications for conservation and management. Pacific Conservation Biology 5: 289-298.

Marsh, H. and Sinclair, D. F. (1989) Correcting for visibility bias in strip transect aerial surveys of aquatic fauna. Journal of Wildlife Management 53 (4): 1017-1024. http://dx.doi.org/10.2307/3809604

McKillop, H. I. (1985) Prehistoric exploitation of the manatee in the Maya and Circum-Caribbean areas. World Archaeology 16 (3): 337-353.

http://dx.doi.org/10.1080/00438243.1985.9979939

Mignucci-Giannoni, A. A. and Beck, C. A. (1998) The diet of the manatee (Trichechus manatus) in Puerto Rico. Marine Mammal Science 14 (2): 394-397.

http://dx.doi.org/10.1111/j.1748-7692.1998.tb00733.x

Morales-Vela, B., Olivera-Gómez, D., Reynolds, J. E., III and Rathbun, G. B. (2000) Distribution and habitat use by manatees (Trichechus manatus manatus) in Belize and Chetumal Bay, Mexico. Biological Conservation 95 (1): 67-75. http://dx.doi.org/10.1016/S0006-3207(00)00009-4

Morales-Vela, B., Padilla-Saldivar, J. A. and MignucciGiannoni, A. A. (2003) Status of the manatee (Trichechus manatus) along the northern and western coasts of the Yucatan Peninsula, Mexico. Caribbean Journal of Science 39 (1): 42-49.
Olivera-Gómez, L. D. and Mellink, E. (2002) Spatial and temporal variation in counts of the Antillean manatee (Trichechus manatus manatus) during distribution surveys at Bahia de Chetumal, Mexico. Aquatic Mammals 28: 285-293.

Olivera-Gómez, L. D. and Mellink, E. (2005) Distribution of the Antillean manatee (Trichechus manatus manatus) as a function of habitat characteristics, in Bahia de Chetumal, Mexico. Biological Conservation 121 (1): 127-133. http://dx.doi.org/10.1016/j.biocon.2004.02.023

Pineda Portillo, N. (1997) Geografía de Honduras. Editorial Guaymuras. Tegucigalpa, Honduras.

Provancha, J. A. and Provancha, M. J. (1988) Long-term trends in abundance and distribution of manatees (Trichechus manatus) in the northern Banana River, Brevard County, Florida. Marine Mammal Science 4 (4): 323-338.

http://dx.doi.org/10.1111/j.1748-7692.1988.tb00541.x

Rathbun, G. B., Powell, J. A. and Cruz, G. (1983) Status of the West Indian manatee in Honduras. Biological Conservation 26 (4): 301-308.

http://dx.doi.org/10.1016/0006-3207(83)90094-0

Reynolds, J. E., III and Odell, D. K. (1991) Manatees and dugongs. Facts on File. New York, USA.

Reynolds, J. E., III and Powell, J. A. (2002) Manatees. Pages 709-720 in Perrin, W.F., Wursig, B. and Thewissen, J.G.M., (Eds) Encyclopedia of Marine Mammals. Academic Press. San Diego, CA, USA.

Self-Sullivan, C. and Mignucci-Giannoni, A. (2008) Trichechus manatus manatus in IUCN 2010. IUCN Red List of Threatened Species. Version 2010.4. [Available online at $<$ www.iucnredlist.org $>$ Consulted on 8 February 2011].

Self-Sullivan, C., Smith, G. W., Packard, J. M. and LaCommare, K. S. (2003) Seasonal occurrence of male Antillean manatees (Trichechus manatus manatus) on the Belize Barrier Reef. Aquatic Mammals 29 (3): 342-354.

Strong, W. D. (1935) Archeological investigations in the Bay Islands, Spanish Honduras. Smithsonian Miscellaneous Collections 92 (14): 1-172. 